Meta Frank

Univerza v Ljubljani

Filozofska fakulteta (doktorska študentka)

metafrank@gmail.com
UDK 811.161.1'243:37.091.3(497.4)

DOI: $10.4312 /$ vestnik.7.229-253

\title{
POUČEVANJE RUŠČINE KOT TUJEGA JEZIKA V SLOVENSKEM PROSTORU
}

\section{UVOD}

Poučevanje ruščine kot tujega jezika ima svoje posebnosti. V pričujočem prispevku bomo poskušali predstaviti, kako se s poučevanjem ruščine spoprijemajo učitelji ${ }^{1}$ ruščine v slovenskem prostoru. Na podlagi podatkov iz vprašalnika, ki je bil učiteljem ruščine posredovan v šolskem letu 2014/2015, bomo ugotovili, kje se ruščina poučuje, kakšna gradiva se pri tem uporabljajo in na katerih področjih ugotavljajo učitelji največje težave pri učenju in usvajanju ruskega jezika.

\section{METODIKA POUČEVANJA RUŠČINE KOT TUJEGA JEZIKA}

Metodiko poučevanja ruščine kot tujega jezika Šibko (2014) opredeljuje kot znanost, ki se ukvarja z raziskovanjem ciljev, vsebin, metod in sredstev, z oblikami učenja ruščine ter s spoznavanjem ruske kulture. Metodika poučevanja ruščine vključuje teorijo didaktike (sistem učiteljevih znanj), upoštevanje različnih konkretnih nalog in pogojev učnega procesa ter oblikovanje praktičnih navad in veščin pri učenju tujega jezika. Tesno se povezuje z drugimi vedami, kot so jezikoslovje, pedagogika, psihologija, kulturologija ipd.

Predmet raziskovanja metodike poučevanja ruščine kot tujega jezika je ruski jezik, ki se ga učijo tuji (ne rusko govoreči) učenci². Sodobna metodika uporablja ruski jezik ne samo kot cilj, ampak tudi kot sredstvo poučevanja (Krjučkova, Moščinskaja 2009).

\subsection{Kratka zgodovina metodike poučevanja ruščine kot tujega jezika}

Teoretične osnove poučevanja ruščine kot tujega jezika niso izum tega tisočletja, ampak imajo bogato in pestro zgodovino.

1 V tekstu uporabljeni besedi moškega spola učitelj, učenec pomenijo tudi ženski obliki (učiteljica, učenka).

2 Beseda učenec se nanaša na učenca, dijaka, študenta, tečajnika, ki se uči ruski jezik. 
Pojem 'ruski jezik kot tuji jezik' (rus. русский язык как иностранный - РКИ) se pojavi v 2. polovici 20. stoletja in je povezan z razvojem poučevanja tujih učencev, ki so se izobraževali v različnih ruskih šolah. Ruski jezik je kot tuji jezik postal obvezni predmet za tujce v ruskih šolah v 50. in 60. letih prejšnjega stoletja (Krjučkova, Moščinskaja 2009). Metodika poučevanja ruščine kot tujega jezika se je kot samostojna znanstvena disciplina razvijala vzporedno z razvojem splošne didaktike tujih jezikov. Zgodovinski razvoj metodike poučevanja ruščine kot tujega jezika lahko prikažemo v petih obdobij (Lebedinskij, Gerbik 2011):

\section{a) 1. obdobje (20.-40. leta 20. stoletja)}

$\mathrm{V}$ tem obdobju se metodika poučevanja ruščine kot tujega jezika oblikuje kot samostojna znanstvena disciplina. $\mathrm{V}$ didaktiki tujih jezikov je omenjeno obdobje zaznamovala predvsem polemika o prednostih in pomanjkljivostih med t. i. zavestno-kontrastivno (rus. сознательно-сопоставительный подход) in neposredno metodo (прямой подход). Prva v ospredje postavlja delo s tekstom, zavestno učenje pravil, na osnovi katerih se oblikujejo govorne navade in veščine, materni jezik pa razume kot oporo pri učenju tujega jezika. Zagovorniki neposredne metode so poudarjali intuitivno usvajanje tujega jezika, slovnica je imela nepomembno vlogo, učenje tujega jezika pa je potekalo brez posredovanja materinščine (Muster-Čenčur 1997: 29). Sredi 30. let 20. stol. se pojavi t. i. kombinirana metoda (rus. комбинированный метод), ki združi omenjena pola. Pri kombinirani metodi se na začetni stopnji učenja tujega jezika ne uporabljajo slovnična pravila ali materni jezik, dopušča pa uporabo prevodov, analizo tekstov in primerjavo z materinščino na nadaljevalnih stopnjah. Celostni koncept procesa usvajanja tujega jezika so poskušali v svojih delih predstaviti tudi nekateri ruski psihologi in jezikoslovci, npr. L. S. Vygotskij, L. V. Ščerba in S. I. Bernštejn (Lebedinskij, Gerbik 2011).

\section{b) 2. obdobje (40.-50. leta 20.stol.)}

Metodika poučevanja tujih jezikov opredeljuje svoja teoretična in praktična izhodišča. Pri vzpostavljanju osnov metodike poučevanja ruščine kot tujega jezika je v tem obdobju pomembno vlogo odigral L. V. Ščerba s svojimi jezikoslovno-didaktičnimi teorijami o prednostih zavestnega učenja tujega jezika ter o pomembnosti primerjav tujega jezika z materinščino (Lebedenskij, Gerbik 2011: 17). Pri praktičnem delu z učenci so se najpogosteje uporabljale naslednje metode: slovnično-prevajalna, zavestno-kontrastivna in kombinirana. V 50. letih 20. stol. je bil glavni poudarek ruskih jezikoslovcev (L. V. Ščerba, I. V. Rahmanov, Z. M. Cvetkova, V. S. Cetlin) na zavestno-kontrastivni metodi poučevanja tujih jezikov, ki kljub prizadevanjem ni pripeljala do glavnega cilja učenja tujega jezika - k sporazumevanju v tujem jeziku. Sovjetski psiholog B. V. Beljajev je zato oblikoval zavestno-praktično metodo (rus. сознательно-практический метод) роučevanja tujih jezikov, ki je poudarjala ustno sporazumevanje in psihološko osnovano uporabo zavestne sistematizacije jezikovnih sredstev in pravil že na začetnih stopnjah učenja ruščine kot tujega jezika (Lebedinskij, Gerbik 2011). 
c) 3. obdobje (60.-sredina 80. let 20. stol.)

Metodika poučevanja ruščine kot tujega jezika se intenzivno razvija in povezuje z drugimi znanstvenimi disciplinami (jezikoslovjem, psihologijo). Raziskuje se vpliv interference, vzpostavi se teorija oblikovanja navad in veščin v procesu učenja tujih jezikov. Razširjena je zavestno-praktična metoda, ki poudarja princip zavestnega učenja in pomen komunikacije, najpomembnejšo vlogo pa ima govorno izražanje. V začetku 70. let postane omenjena metoda splošno priznana, raziskovalci jo predvsem dopolnjujejo in izpopolnjujejo. $\mathrm{V}$ zahodnem svetu se pojavijo podobne tendence. Direktna metoda najde svoje naslednike $v$ avdio-lingvalni in avdio-vizualni metodi. Njihovo nasprotje predstavljajo kognitivne metode, ki učenje jezika pojmujejo kot logični miselni proces in se v marsičem opirajo na spoznanja v delih L. S. Vigotskega, S. I. Bernštejna in A. A. Leontjeva (Lebedinskij, Gerbik 2011).

\section{č) 4. obdobje (konec 80. let-konec 90. let 20. stol.)}

$\mathrm{V}$ tem obdobju se metodika izpopolnjuje in upošteva spoznanja psihologije ter različnih komunikacijskih teorij. Razvijajo se nove metode poučevanja, kot so komunikacijska metoda, komunikacijsko-individualna metoda, problemsko zasnovano učenje, intenzivne metode poučevanja ipd. Pomembno vlogo igra motivacija, realne potrebe učencev v sporazumevalnem procesu, praktična naravnanost ciljev pri učenju tujega jezika, funkcionalno izbrano gradivo, individualne značilnosti učencev, kulturološke značilnosti ... V metodiki ruščine kot tujega jezika postane zanimiva komunikacijska metoda poučevanja E. I. Passova, različne modifikacije intenzivnih metod (G. A. Kitajgorodskaja, L. Š. Gegečkori, I. Ju. Šehter). V omenjenem obdobju lahko zasledimo enotnost v pristopih k metodiki poučevanja ruskega jezika kot tujega jezika in metodah poučevanja tujih jezikov na zahodu (Lebedinskij, Gerbik 2011).

\section{d) 5. obdobje (od konca 90. let 20. stol.)}

Metodika poučevanja ruščine kot tujega jezika se preoblikuje v kompleksno znanost, ki povezuje različna področja in se dotika vseh področij poučevanja, procesa usvajanja ter individualnih značilnosti učencev. K razvoju rusistike je še posebej prispevala ustanovitev Državnega inštituta za ruski jezik A. S. Puškina v Moskvi, izhajati je začel mesečnik Русский язык за рубежсом (Russkij jazyk za rubežom), oblikovala se je Mednarodna zveza učiteljev ruskega jezika in literature (rus. МАПРЯЛ), nastale so specializirane založbe, kot so Zlatoust, Ruski jazyk.Kursy idr. Leta 2007 se oblikuje sklad Русский мир (Russkij mir), ki skrbi za širjenje ruskega jezika in spodbuja njegovo učenje. Leta 2008 Ruska federacija ustanovi državno agencijo Россотрудничество (Rossotrudničestvo), ki skrbi za realizacijo projektov, s katerimi krepi mednarodne povezave ter sodelovanje na humanitarnem področju. 


\section{VSEBINA UČENJA IN POUČEVANJA RUŠČINE KOT TUJEGA JEZIKA}

Vsebina učenja in poučevanja ruščine kot tujega jezika obsega vse, kar mora učitelj naučiti učence, ter vse, kar se morajo učenci naučiti v učnem procesu (Ščukin 2003: 124). Dejstva o jezikovnem sistemu so le del vsebine učenja in poučevanja, pomembno vlogo imajo tudi navade in veščine, ki predstavljajo praktično zmožnost uporabe usvojenih znanj v različnih sporazumevalnih situacijah. Vsebino učenja in poučevanja ruščine kot tujega jezika predstavljajo naslednji sestavni elementi (Ščukin 2003): sredstva sporazumevanja (npr. posamezni glasovi, besede, kulturološke značilnosti), znanje o uporabi omenjenih sredstev, navade in veščine (omogočajo uporabo jezika), podočja, teme in sporazumevalne situacije (realizacija vsebine) ter besedila, ki predstavljajo njeno materialno osnovo. Končni cilj usvajanja vsebine učenja in poučevanja je oblikovanje komunikativne kompetence, ki omogoča ustno in pisno rabo jezika v različnih sporazumevalnih situacijah.

Vsebina učenja in poučevanja ruščine kot tujega jezika mora upoštevati učne načrte, programe, cilje in ravni znanja učencev.

\section{CILJI IN NALOGE METODIKE POUČEVANJA RUŠČINE KOT TUJEGA JEZIKA}

Šibko (2014) cilj učenja razume kot vnaprej načrtovan rezultat dejavnosti v procesu učenja tujega jezika, ki vključuje tudi izbor različnih nalog, pristopov in materiala. V okviru določenega cilja se rešujejo različne naloge $\mathrm{v}$ skladu s konkretnimi pogoji pouka, ravnmi znanja ipd. Šibko (2014: 31) loči štiri glavne cilje pri učenju ruščine kot tujega jezika, in sicer:

1. praktični,

2. splošnoizobraževalni,

3. vzgojni in

4. razvojni cilj.

V skladu s praktičnim ciljem učencem predstavimo jezikovni sistem tujega jezika, ga omenjeni sistem naučimo uporabljati v sporazumevalnem procesu ter učence seznanimo $\mathrm{z}$ veščinami, ki mu bodo pomagale pri učenju tujega jezika. Splošnoizobraževalni cilj učenja vključuje znanja o državi, v kateri se tuji jezik govori, tudi s pomočjo elementov, ki jih vsebuje sam jezik. Vzgojni cilj pomeni, da vzpostavimo spoštljiv in dobronameren odnos do tujega naroda, kulture in jezika, naučimo učence kritičnega razmišljanja ter vzpostavimo sistem moralnih vrednot. Pri razvojnem cilju gre za spodbujanje usvajanja, aktivacijo spomina, pozornosti, mišljenja in čustev. Učitelj mora razvijati motivacijo za učenje jezika in spoznavanje tuje kulture ter različne jezikovne zmožnosti (Šibko 2014: 31). 


\section{UČENJE IN POUČEVANJE RUŠČINE V SLOVENSKEM PROSTORU}

Ruščina si utira pot v šolski sistem v obratni smeri kot drugi tuji jeziki. Največje povpraševanje po ruščini je pri ljudeh, ki so zaključili formalno izobraževanje in se dodatno izobražujejo.

Ruščina je v osnovni šoli triletni predmet, ki se izvaja dve uri tedensko, skupno 204 ure. Učenec lahko po enem ali dveh letih izstopi iz programa. Z učenjem ruščine lahko začne tudi v 8. ali 9. razredu, če ima ustrezno predznanje (Urbas, Vozelj 2009: 4). Po podatkih, ki smo jih pridobili z Ministrstva za izobraževanje, znanost in šport v skladu z Organizacijskim poročilom za osnovne šole, se je ruščina kot izbirni predmet v osnovnih šolah začela poučevati v šolskem letu 2007/2008. Število učencev, ki se odločajo za učenje ruščine, narašča. Pri tem je potrebno omeniti, da Ministrstvo s podatki o učenju ruščine kot fakultativnega predmeta (tudi v krožkih) ne razpolaga, kar pomeni, da je osnovnošolskih učencev, ki se učijo ruščine, dejansko nekoliko več, kot prikazuje spodnja tabela.

Tabela 1: Število učencev v okviru obveznih izbirnih vsebin v OŠ po posameznih šolskih letih

\begin{tabular}{|c|c|}
\hline Šolsko leto & Število učencev \\
\hline $2007 / 2008$ & 21 \\
\hline $2008 / 2009$ & 55 \\
\hline $2009 / 2010$ & 65 \\
\hline $2010 / 2011$ & 58 \\
\hline $2011 / 2012$ & 69 \\
\hline $2012 / 2013$ & 90 \\
\hline $2013 / 2014$ & 80 \\
\hline $2014 / 2015$ & 93 \\
\hline
\end{tabular}

Vir: MIZS (OR poročilo za osnovne šole)

Ruščina ima v slovenskih gimnazijah zagotovljen status maturitetnega predmeta. Učenci lahko ruščino večinoma izberejo kot drugi ali tretji tuji jezik (Urbas, Vozelj 2008: 5). Po podatkih, ki so nam jih posredovali iz Državnega izpitnega centra (RIC), število dijakov, ki se odločajo za ruščino na maturi od šolskega leta 1994/1995, počasi, a vztrajno narašča. 
Tabela 2: Število dijakov, ki so opravljali maturo iz ruščine po posameznih šolskih letih

\begin{tabular}{|c|c|}
\hline Šolsko leto & $\begin{array}{l}\text { Število dijakov na obeh } \\
\text { ravneh in rokih }\end{array}$ \\
\hline 1994/1995 & 2 \\
\hline 1995/1996 & 1 \\
\hline 1996/1997 & 13 \\
\hline 1997/1998 & 12 \\
\hline 1998/1999 & 10 \\
\hline $1999 / 2000$ & 10 \\
\hline $2000 / 2001$ & 8 \\
\hline $2001 / 2002$ & 8 \\
\hline $2002 / 2003$ & 9 \\
\hline $2003 / 2004$ & 8 \\
\hline $2004 / 2005$ & 18 \\
\hline $2005 / 2006$ & 11 \\
\hline $2006 / 2007$ & 19 \\
\hline 2007/2008 & 24 \\
\hline $2008 / 2009$ & 15 \\
\hline 2009/2010 & 33 \\
\hline 2010/2011 & 34 \\
\hline $2011 / 2012$ & 46 \\
\hline $2012 / 2013$ & 56 \\
\hline $2013 / 2014$ & 52 \\
\hline $2014 / 2015$ & 53 \\
\hline
\end{tabular}

Vir: Podatki Državnega izpitnega centra

Učenci lahko svoje znanje ruščine nadgradijo na Filozofski fakulteti v Ljubljani, kjer se izvaja univerzitetni dvodisciplinarni študijski program Rusistika, na različnih tečajih v jezikoslovnih šolah in ljudskih univerzah po Sloveniji. V Ljubljani igra pomembno vlogo pri razširjanju ruskega jezika in kulture Ruski center znanosti in kulture ter društva in skladi, kot na primer Zavod Vesela dRuščina, Društvo Slovenija-Rusija idr.

\subsection{Učenje ruščine kot tujega jezika v slovenskem jezikovnem okolju}

Bykova (2014: 21) loči tri elemente, ki opredeljujejo učenje in poučevanje ruščine kot tujega jezika v določenem izobraževalnem okolju: a) tradicionalni izobraževalni sistem, b) sodobni izobraževalni sistem in c) prisotnost/odsotnost tujejezičnega učitelja (naravnega 
govorca). Izobraževalni sistem predstavlja pomemben del določene kulture in je tesno povezan s psihologijo in delovanjem njenih nositeljev. Učitelj tujih jezikov mora upoštevati izobraževalni sistem države, v kateri poučuje, hkrati pa pri pouku učencem približati tujejezično kulturno, jezikovno in izobraževalno okolje.

Učenje in poučevanje ruščine v slovenskem, torej tujem oz. neruskem socialno-kulturnem okolju, ima določene značilnosti, ki jih je potrebno upoštevati v primerjavi z učenjem in poučevanjem ruščine kot tujega jezika v ruskem prostoru. Motivacija učencev, ki se ruščino učijo v Rusiji, je drugačne narave, poleg tega jo spodbuja in krepi zunanje okolje. Motivacija učencev ruščine v Sloveniji je zgrajena na drugačnih osnovah, npr. učence zanima ruska kultura, književnost, znanje ruščine zanje predstavlja dodatno prednost pri iskanju zaposlitve ipd.

Učitelj ruščine kot tujega jezika mora pri svojem delu upoštevati teoretična izhodišča o učenju in poučevanju ruščine kot tujega jezika, cilje in vsebine, ki jih določajo učni načrti, poleg tega pa mora pri izvajanju pouka vzpostavljati komunikacijske situacije, ki bodo pripomogle k uporabi tujejezičnega govora, saj običajni slovenski učenec nima veliko možnosti za vsakdanje sporazumevanje v ruščini.

V šolskem letu 2014/2015 smo med učitelje ruščine razdelili vprašalnik, ki je bil sestavljen iz 28 vprašanj in v katerem smo želeli izvedeti, kakšna gradiva uporabljajo učitelji ter s kakšnimi težavami se srečujejo pri poučevanju ruščine kot tujega jezika v slovenskem prostoru. Vprašalnik je bil posredovan 58 učiteljem ruščine, nanj je odgovorilo zgolj 29 učiteljev (50 \%). S prvim vprašanjem smo želeli izvedeti, kje vprašani poučujejo ruščino. Odgovori so predstavljeni v spodnji tabeli.

Tabela 3: Kje poučujete ruščino?

\begin{tabular}{|c|c|}
\hline Odgovori & $\begin{array}{c}\text { Število učiteljev, ki je } \\
\text { odgovor izbralo }\end{array}$ \\
\hline $\begin{array}{c}\text { na jezikovni šoli } \\
\text { (na jezikovnih tečajih) }\end{array}$ & 13 \\
\hline na gimnaziji & 9 \\
\hline v osnovni šoli & 4 \\
\hline na fakulteti & 3 \\
\hline
\end{tabular}

\subsection{Učbeniki in gradiva pri poučevanju ruščine kot tujega jezika}

Avtorji in založniki morajo pri snovanju učbenikov in gradiv upoštevati vrsto različnih dejavnikov, ki delajo učbenike uporabne v različnih izobraževalnih sistemih, ki učencem posredujejo potrebna znanja in veščine ter vedenja o tuji državi, narodu, kulturi, načinu življenja, znanstvenih in tehnoloških dosežkih ipd. Učbenik mora prispevati k lažjemu in bolj učinkovitemu učenju in poučevanju, poleg tega pa mora biti zanimiv, všečen ter strukturiran tako, da je njegova uporaba jasna in enostavna (Vjatjutnev 1981). 
Velike ruske založbe, kot so Zlatoust, Russkij jazyk. Kursy ali Flinta-Nauka, uporabnike zalagajo z množico raznovrstnih učbenikov, namenjenih različnim starostnim in interesnim skupinam $\mathrm{z}$ različnim predznanjem. V slovenskem prostoru so $\mathrm{v}$ zadnjem desetletju nastali učbeniki za učenje ruščine, namenjeni slovenskim učencem, ki opozarjajo na jezikovno interferenco ter na razlike in podobnosti med jezikoma (avtorice omenjenih učbenikov so Janja Urbas, Marina Spanring-Poredoš, Tatjana Komarova).

S pomočjo prvega sklopa vprašanj v vprašalniku smo od učiteljev ruščine želeli izvedeti:

a) ali pri svojem delu uporabljajo učbenik oz. učbeniški komplet in kateri,

b) ali je v učbenik, ki ga uporabljajo, vključeno tudi avdio-vizualno gradivo (npr. CD, DVD) in ali omenjeno gradivo tudi uporabljajo,

c) ali uporabljajo tudi priročnik za učitelje, če slednji obstaja kot dodatek k navedenemu učbeniku,

č) ali učencem posredujejo dodatni material (npr. fotokopije delovnih listov z dodatno razlago in vajami) ter

d) kakšen dodatni material posredujejo učencem (če ga) in s kakšnim namenom.

Iz odgovorov na omenjena vprašanja je razvidno, da učitelji ruščine v slovenskih šolah in na jezikovnih tečajih uporabljajo veliko različnih učbenikov. Nekatere jezikovne šole in učitelji so izdelali lastno interno gradivo, večina učiteljev pa se pri poučevanju ruščine poslužuje več različnih učbenikov oz. učbeniških kompletov.

Tabela 4: Podatki o uporabi učbenikov oz. wčbeniskih kompletov in lastnih gradiv

\begin{tabular}{|c|c|}
\hline Odgovori & Število učiteljev \\
\hline $\begin{array}{c}\text { kombiniranje več učbenikov in } \\
\text { lastnega gradiva }\end{array}$ & 12 \\
\hline uporaba samo enega učbenika & 11 \\
\hline uporaba lastnega gradiva & 6 \\
\hline
\end{tabular}

Vprašani so v svojih odgovorih navedli 11 različnih učbenikov, ki so v spodnji tabeli predstavljeni po pogostosti njihovega pojavljanja. V tabeli je podan naslov učbenika, avtor in založba ter podatek o tem, ali posamezni učbenik vsebuje avdio-vizualno gradivo $(\mathrm{CD}$, DVD, kasete ipd.) in priročnik za učitelje. 
Tabela 5: Pregled učbenikov, ki jih uporabljajo učitelji ruščine $v$ slovenskem prostoru

\begin{tabular}{|c|c|c|c|c|}
\hline Naslov učbenika & Avtor; založba & $\begin{array}{l}\text { Avdio- } \\
\text { vizualno } \\
\text { gradivo }\end{array}$ & $\begin{array}{l}\text { Priročnik } \\
\text { za učitelje }\end{array}$ & $\begin{array}{l}\text { Število učiteljev, ki } \\
\text { učbenik uporablja }\end{array}$ \\
\hline Poehali & $\begin{array}{l}\text { S. Černyšov, A. Černyšova; } \\
\text { Zlatoust }\end{array}$ & $\mathrm{da}$ & ne & 9 \\
\hline Okno & M. Gerber; Klett & da & ne & 7 \\
\hline Žili-byli & $\begin{array}{l}\text { L. V. Miller, L. V. Politova, I. } \\
\text { Ja. Rybakova; Zlatoust }\end{array}$ & da & da & 7 \\
\hline Russkij klass & $\begin{array}{l}\text { L. L. Vohmina; Russkij } \\
\text { jazyk. Kursy }\end{array}$ & da & ne & 2 \\
\hline $\begin{array}{l}\text { Ja i ty ......mi } \\
\text { in vi }\end{array}$ & $\begin{array}{l}\text { Marina Spanring-Poredoš; } \\
\text { Znanstvena založba FF }\end{array}$ & da & ne & 2 \\
\hline $\begin{array}{l}\text { komplet } \\
\text { učbenikov Orbita }\end{array}$ & $\begin{array}{l}\text { P. Piper, M. Petković, } \\
\text { S. Mirković; Zavod za } \\
\text { udžbenike }\end{array}$ & da & ne & 2 \\
\hline $\begin{array}{l}\text { Survival Russian: } \\
\text { Govorite pravil'no! }\end{array}$ & $\begin{array}{l}\text { N. B. Karavanova; Russkij } \\
\text { jazyk.Kursy }\end{array}$ & da & ne & 2 \\
\hline $\begin{array}{l}\text { Russkij jazyk: } 5 \\
\text { elementov }\end{array}$ & T. Esmantova; Zlatoust & $\mathrm{da}$ & da & 1 \\
\hline $\begin{array}{l}\text { Russkij jazyk po- } \\
\text { novomu }\end{array}$ & M. Aksenova; Zlatoust & da & ne & 1 \\
\hline $\begin{array}{l}\text { Russkij jazyk: lgry } \\
\text { i zadanija }\end{array}$ & K. Čakmišjan; ELI & ne & ne & 1 \\
\hline $\begin{array}{l}\text { Situacije, mnenja, } \\
\text { vaje }\end{array}$ & J. Urbas & ne & ne & 1 \\
\hline
\end{tabular}

Med naštetimi učbeniki je najbolj priljubljen učbenik Poehali, ki je sestavljen iz več delov, v Sloveniji pa ga uporabljajo na jezikovnih šolah, gimnazijah ter na fakulteti. Po priljubljenosti mu sledita učbenika Okno in Žili-byli. Učbenik Okno se uporablja predvsem v gimnazijah, samo eden od vprašanih se ga poslužuje tudi v osnovni šoli. Učbenik Žili-byli uporabljajo učitelji na gimnazijah ter na jezikovnih šolah.

Večina učbenikov sicer vsebuje avdio-vizualno gradivo, ki ga učitelji s pridom uporabljajo, samo dva iz navedenih učbenikov pa imata tudi izdelan priročnik za učitelje, ki bi izvajalcem pouka z didaktičnimi nasveti pomagal in svetoval. Štirje vprašani uporabljajo takšen priročnik (to so predvsem tisti, ki uporabljajo učbenik Žili-byli).

V prvem sklopu vprašanj smo želeli izvedeti, ali učitelji ruščine posredujejo tudi dodatni material, kakšen dodatni material ter s kakšnim namenom. Vsi vprašani (29) so odgovorili pritrdilno na vprašanje, ali svojim učencem posredujejo tudi dodatni material (npr. fotokopije delovnih listov z dodatno razlago in vajami). Pri vprašanju - S kakšnim namenom posredujete dodatni material pri pouku ruščine? -smo dobili rezultate (vprašani so morali izbrati največ tri odgovore), predstavljene v Tabeli 6 . 
Tabela 6: S kakšnim namenom posredujete dodatni material pri pouku ruščine (npr. fotokopije delovnih listov, dodatne razlage, besedila)?

\begin{tabular}{|l|c|}
\hline Odgovori & $\begin{array}{c}\text { Število učiteljev, ki } \\
\text { je odgovor izbralo }\end{array}$ \\
\hline a) za utrjevanje slovnice in slovničnih pravil & 26 \\
\hline b) za usvajanje in pravila besedišča & 12 \\
\hline $\begin{array}{l}\text { c) za urjenje natančnosti in pravilnosti izgovorjave, } \\
\text { naglasa, intonacije }\end{array}$ & 7 \\
\hline $\begin{array}{l}\text { č) za urjenje pisave, utrjevanje pravopisnih pravil ter } \\
\text { pravil pisnega sistema jezika }\end{array}$ & 6 \\
\hline d) za interpretacijo besedil z glasnim branjem & 5 \\
\hline $\begin{array}{c}\text { e) za širjenje znanja o kulturi in družbi (npr. ruska } \\
\text { vljudnostna pravila, funkcionalne zvrsti jezika ...) }\end{array}$ & 9 \\
\hline $\begin{array}{c}\text { f) za urjenje komunikacije v konkretnih situacijah } \\
\text { (tekočnost, pomenska natančnost ...) }\end{array}$ & 9 \\
\hline g) drugo & 3 \\
\hline
\end{tabular}

Največ vprašanih uporablja dodatno gradivo za utrjevanje slovnice in slovničnih pravil. Pri zadnji možnosti (drugo) smo po enkrat dobili naslednje variante odgovorov:

- $\quad$ za popestritev pouka,

- $\quad$ za dopolnjevanje učbenika, ki se zdi pomanjkljiv in nesistematičen,

- $\quad$ zaradi odsotnosti učbenika.

Z vprašanjem o tem, kakšen dodatni material posredujejo učitelji pri pouku ruščine (izbirali so med petimi ponujenimi odgovori, izbrati so morali največ tri), smo dobili rezultate, kot jih prikazuje Tabela 7.

Tabela 7: Kakšen dodatni material posredujete pri pouku ruščine?

\begin{tabular}{|l|c|}
\hline Odgovori & $\begin{array}{c}\text { Število učiteljev, ki } \\
\text { je odgovor izbralo }\end{array}$ \\
\hline $\begin{array}{l}\text { a) neprirejena ruska besedila (npr. članki iz revij, } \\
\text { ruske internetne strani, pesmi ...) }\end{array}$ & 18 \\
\hline b) slikovni material & 17 \\
\hline c) avtentične avdio in video posnetke & 12 \\
\hline č) prirejena besedila & 1 \\
\hline d) drugo: & 1 \\
\hline $\begin{array}{l}\text { kartončke za slovnično utrjevanje, urjenje } \\
\text { izgovorjave in branje }\end{array}$ & \\
\hline $\begin{array}{l}\text { neavtentične avdio posnetke, ker jih } \\
\text { učbeniški komplet nima }\end{array}$ & \\
\hline
\end{tabular}


Iz odgovorov na vprašanja je razvidno, da večina (26) učiteljev uporablja kot dodatno gradivo avtentične avdio in video posnetke, pogosto pa uporabljajo tudi neprirejena ruska besedila ter slikovni material.

Učitelji ruščine uporabljajo vrsto različnih učbenikov in učbeniških kompletov, ki jih dopolnjujejo z dodatnim materialom. Trenutno ne obstaja predpisan učbenik za pouk ruščine, ki bi bil potrjen s strani Zavoda Republike Slovenije za šolstvo. Večina omenjenih učbenikov je nastala v Rusiji, zato ne upošteva posebnosti, napak in težav, ki se pojavljajo pri učenju ruščine v slovenskem prostoru. V učbenike je običajno vključeno tudi avdio-vizualno gradivo, ki ga učitelji s pridom uporabljajo, le peščica učbenikov pa ima izdelan tudi priročnik za učitelje. Kot dodatno gradivo učitelji uporabljajo predvsem avtentične video in avdio posnetke, neprirejena ruska besedila ali slikovni material, in sicer predvsem z namenom utrjevanja slovnice in slovničnih pravil.

\subsection{Težave in napake slovenskih učencev pri razvijanju različnih zmožnosti}

Napake in težave so sestavni del učenja tujega jezika na vseh stopnjah. Napake so odstopanja od pričakovanega, ustreznega in pravilnega in pomenijo določeno vrsto »neuspešnosti« v jezikovni produkciji (Pirih Svetina 2003: 18). Gre za oblike, ki jih v enakem kontekstu in v enakih pogojih govorci prvega jezika ne bi tvorili (Pirih Svetina 2003: 17). Napaka se torej kaže kot odklon od jezikovne norme in je kazalec trenutne nezmožnosti pravilne uporabe tujega jezika (Pirih Svetina 2003).

Da bi lahko preprečili napake, je potrebno poznati njihove vzroke (jezikovne in psihološke). Po mnenju Varaksine (2014) lahko glavni vzrok za napake učencev, ki se učijo ruščine kot tujega jezika, imenujemo »pritisk jezikovnega sistema«. Učenec poskuša ruski jezik prenesti v sistem maternega jezika. Omenjeni proces poteka naravno in skorajda neodvisno od individualnih značilnosti posameznika. V skladu s psiholingvistiko je vsaka (jezikovna) napaka interpretacija procesa usvajanja tujega jezika in tako povezana z zavestnim ali podzavestnim primerjanjem maternega s tujim jezikom. Napako lahko razumemo kot specifično vrsto razlage lastnega sveta s pomočjo sredstev tujega jezika. Prenašanje lastne podobe sveta privede do neustrezne rabe jezikovnih pravil v tujem jeziku.

Napake so plod postopnega izgrajevanja lastnega sistema pravil v ciljnem jeziku, in sicer se ta proces vrši v t. i. vmesnem jeziku. V skladu s teorijo kontrastivne analize jezikovna zmožnost maternega jezika omejuje učenca pri usvajanju zakonitosti struktur v tujem jeziku. Odkloni od norme (napake) kažejo aktivnost učencev na poti proti ciljnemu jeziku: strategije izogibanja, izpuščanja itd. Na ta način si učenci organizirajo in sistematizirajo svoj jezik. Vmesni jezik učencev je skupek problemov in strategij učencev (Muster, 1997). V procesu usvajanja tujega jezika učenci prek vmesnih stopenj gradijo strategije, ki jim omogočajo izražanje v tujem jeziku, četudi ne poznajo pravil. Vmesne stopnje 
predstavljajo vsakokratni vmesni jezik učencev. Napredovanje ni vedno linearno, pogosto prihaja pri učencih do vračanja k prejšnjim stopnjam, kar se kaže v t. i. začetniških napakah. Teorija vmesnega jezika tako predpostavlja, da cilj učenja tujega jezika ni tuj jezik, kot ga uporabljajo rojeni govorci, ampak tuj jezik kot neka posebna različica omenjenega jezika. Z usvajanjem tujega jezika lahko postanemo njegov bolj ali manj spretni uporabnik (ne pa 'pravi' govorec) (Pirih Svetina 2003).

Z drugim sklopom vprašanj, ki je bil najobsežnejši in sestavljen iz 16 vprašanj, smo od učiteljev poskušali natančneje izvedeti, kje se najpogosteje pojavljajo težave in napake pri učenju ruščine in zakaj.

Kot glavne vzroke za težave pri učenju ruskega jezika so učitelji navedli naslednje (izbrali so lahko največ tri odgovore med desetimi danimi možnostmi):

Tabela 8: Kateri so glavni vzroki za težave pri učenju ruskega jezika?

\begin{tabular}{|l|c|}
\hline Odgovori & Število učiteljev, ki je odgovor izbralo \\
\hline a) prevelike zahteve učnega načrta & 6 \\
\hline $\begin{array}{l}\text { b) premajhna prizadevnost učencev in nizka } \\
\text { motiviranost }\end{array}$ & 1 \\
\hline c) neprimerne učne metode & 1 \\
\hline č) usposobljenost učiteljev & 11 \\
\hline d) učenci neredno opravljajo domače naloge & 16 \\
\hline e) različne sposobnosti učencev & 10 \\
\hline f) učbeniki & 10 \\
\hline g) premalo časa za utrjevanje in vaje & 12 \\
\hline h) premalo tedenskih ur ruščine & prekomerno poudarjanje slovnice ipd.* \\
\hline i) drugo & \\
\hline
\end{tabular}

Iz Tabele 8 je razvidno, da so glavni vzroki za težave pri učenju ruščine po mnenju učiteljev različne sposobnosti učencev, premalo tedenskih ur ruščine, neredno opravljanje domačih nalog, učbeniki, premalo časa za utrjevanje in vaje, premajhna prizadevnost učencev in nizka motiviranost. Samo enkrat so učitelji izbrali odgovor 'neprimerne učne metode' ali odgovor 'usposobljenost učiteljev'. Nihče od vprašanih se ni odločil za možnost, ki kot glavni vzrok za težave pri učenju ruščine opredeljuje prevelike zahteve učnega načrta. Pri zadnji možnosti za odgovor so lahko učitelji navedli morebitne druge vzroke* - tu smo dobili še nekaj dodatnih razlag, kot npr.: preveliko poudarjanje slovnice, neredna prisotnost pri pouku, redke priložnost za uporabo naučene snovi ali neprimerna ura za izvajanje jezikovnega tečaja (utrujenost).

Pri učenju ruščine tako kot pri učenju slehernega drugega tujega jezika učenci razvijajo zmožnosti slušnega in bralnega razumevanja, govornega razumevanja ter govornega in pisnega sporočanja. V skladu s podatki iz vprašalnika je največ težav zaslediti pri razvijanju zmožnosti pisnega sporočanja (Tabela 9). 
Tabela 9: Pri doseganju katerih operativnih ciljev poučevanja ruščine se pojavljajo najuečje težave?

\begin{tabular}{|l|c|}
\hline Odgovori & Število učiteljev, ki je odgovor izbralo \\
\hline a) pri slušnem razumevanju & 3 \\
\hline b) pri bralnem razumevanju & 1 \\
\hline c) pri ustnem sporočanju & 4 \\
\hline č) pri ustnem sporazumevanju & 4 \\
\hline d) pri pisnem sporočanju & 15 \\
\hline
\end{tabular}

Z dodatnimi vprašanji smo želeli natančneje ugotoviti, kje se najpogosteje pojavljajo težave pri doseganju posameznih prej navedenih zmožnostih (Tabela 10-Tabela 14).

Tabela 10: Kje se najbolj pogosto pojavljajo težave pri slušnem razumevanju?

\begin{tabular}{|l|c|}
\hline Odgovori & $\begin{array}{c}\text { Število učiteljev, ki je } \\
\text { odgovor izbralo }\end{array}$ \\
\hline a) Učenci ne razumejo govora učitelja. & $/$ \\
\hline $\begin{array}{l}\text { b) Učenci ne razumejo besedila, posnetega v } \\
\text { pedagoške namene. }\end{array}$ & 14 \\
\hline c) Učenci ne razumejo neprirejenega besedila. & 1 \\
\hline č) Učenci ne ločijo posameznih glasov. & $/$ \\
\hline d) Učenci ne prepoznajo ključnih informacij. & 9 \\
\hline e) Učenci ne prepoznajo podrobnosti. & 1 \\
\hline $\begin{array}{l}\text { f) Učenci ne prepoznajo namena in } \\
\text { razpoloženja govorca. }\end{array}$ & 3 \\
\hline $\begin{array}{l}\text { g) Učenci ne znajo povzeti poslušanega } \\
\text { besedila. }\end{array}$ & $/$ \\
\hline h) drugo & \\
\hline
\end{tabular}

Na področju slušnega razumevanja so učitelji največ težav zasledili pri razumevanju neprirejenih besedil ter prepoznavanju podrobnosti, večjih težav pa ni zaslediti pri razumevanju učitelja ali teksta, ki je posnet v pedagoške namene, pri ločevanju posameznih glasov, prepoznavanju ključnih informacij, povzemanju slišanega in prepoznavanju namena ali razpoloženja govorca. 
Tabela 11: Kje najpogosteje pojavljajo težave pri bralnem razumevanju?

\begin{tabular}{|l|c|}
\hline Odgovori & $\begin{array}{c}\text { Število učiteljev, ki je } \\
\text { odgovor izbralo }\end{array}$ \\
\hline $\begin{array}{l}\text { a) Učenci ne razumejo sporočila prebranega } \\
\text { prirejenega besedila. }\end{array}$ & 1 \\
\hline $\begin{array}{l}\text { b) Učenci ne razumejo sporočila prebranega } \\
\text { neprirejenega besedila. }\end{array}$ & 11 \\
\hline c) Učenci ne prepoznajo ključnih informacij. & $/$ \\
\hline č) Učenci ne prepoznajo podrobnosti. & 11 \\
\hline d) Učenci nepravilno izpisujejo podatke. & 1 \\
\hline $\begin{array}{l}\text { e) Učenci ne prepoznavajo besedil različnih } \\
\text { zvrsti in njihovih značilnosti. }\end{array}$ & $/$ \\
\hline f) Učenci nepravilno povzemajo besedilo. & 4 \\
\hline g) drugo & (Učenci nimajo težav.) \\
\hline
\end{tabular}

Največ napak, ki se pojavljajo pri bralnem razumevanju, učitelji ugotavljajo pri razumevanju sporočila prebranega neprirejenega besedila ter pri prepoznavanju podrobnosti.

Tabela 12: Kje najbolj pogosto zasledite težave pri ustnem sporazumevanju?

\begin{tabular}{|c|c|}
\hline Odgovori & $\begin{array}{l}\text { Število učiteljev, ki je } \\
\text { odgovor izbralo }\end{array}$ \\
\hline $\begin{array}{l}\text { a) Učenci se glede na jezikovne norme izražajo } \\
\text { pravilno, vendar je sporočilo še vedno jasno. }\end{array}$ & 10 \\
\hline $\begin{array}{l}\text { b) Učenci se glede na jezikovne norme izražajo } \\
\text { nepravilno, tudi sporočilo ni jasno. }\end{array}$ & / \\
\hline $\begin{array}{l}\text { c) Učenci imajo težave s pravilnim izgovorom, } \\
\text { naglasom in stavčno intonacijo. }\end{array}$ & 8 \\
\hline $\begin{array}{l}\text { č) Učenci se komunikacijsko neustrezno } \\
\text { odzivajo na pobudo in sporočila sogovornika. }\end{array}$ & 1 \\
\hline $\begin{array}{l}\text { d) Učenci ne poznajo in ne upoštevajo } \\
\text { neverbalnih sredstev sporazumevanja. }\end{array}$ & / \\
\hline $\begin{array}{l}\text { e) Učenci ne zmorejo samostojno argumentirati, } \\
\text { razložiti ali opisati svojih čustev, mnenj ipd. }\end{array}$ & 8 \\
\hline $\begin{array}{l}\text { f) Učenci težko spregovorijo, ne sodelujejo v } \\
\text { pogovorih v razredu, ne vzpostavijo stika. }\end{array}$ & 1 \\
\hline g) drugo & 1 \\
\hline
\end{tabular}

Največ težav pri ustnem sporazumevanju se po mnenju učiteljev kaže pri tem, da se učenci glede na jezikovne norme izražajo nepravilno, vendar je njihovo sporočilo še vedno razumljivo. Učenci imajo tudi težave s pravilnim izgovorom, naglasom in stavčno intonacijo ter ne zmorejo samostojno argumentirati, razložiti ali opisati svojih čustev in 
mnenj. Težav na področju ustnega sporazumevanja ni zaslediti pri komunikacijskih odzivih na sporočilo sogovornika ali prepoznavanju in upoštevanju neverbalnih sredstev sporazumevanja.

Tabela 13: Kje se najbolj pogosto pojavljajo težave pri govornem sporočanju?

\begin{tabular}{|l|c|}
\hline Odgovori & $\begin{array}{c}\text { Število učiteljev, ki je } \\
\text { odgovor izbralo }\end{array}$ \\
\hline $\begin{array}{c}\text { a) Učenci se nepravilno in nejasno izražajo } \\
\text { glede na veljavne jezikovne norme. }\end{array}$ & 8 \\
\hline $\begin{array}{l}\text { b) Učenci ne tvorijo ustreznega ustnega } \\
\text { sporočila glede na situacijo, govorni } \\
\text { položaj in namen sporočila. }\end{array}$ & 2 \\
\hline $\begin{array}{l}\text { c) Učenci ne zmorejo samostojno } \\
\text { argumentirati, razložiti ali opisati svojih } \\
\text { čustev ipd. }\end{array}$ & 12 \\
\hline $\begin{array}{l}\text { č) Učenci ne zmorejo ustno povzeti } \\
\text { besedila, ki služi kot iztočnica za } \\
\text { izražanje. }\end{array}$ & 2 \\
\hline $\begin{array}{l}\text { d) Učenci ne zmorejo ustrezno } \\
\text { preoblikovati prebranega ali } \\
\text { poslušanega besedila, ki služi kot } \\
\text { iztočnica za izražanje. }\end{array}$ & \\
\hline e) drugo & 2 \\
\hline
\end{tabular}

Pri govornem sporočanju učenci najpogosteje ne zmorejo samostojno argumentirati, razložiti ali opisati svojih mnenj in čustev, večkrat se tudi nepravilno in nejasno izražajo glede na veljavne jezikovne norme.

Tabela 14: Kje se najpogosteje pojavljajo težave pri pisnem sporočanju?

\begin{tabular}{|l|c|}
\hline Odgovori & $\begin{array}{c}\text { Število učiteljev, ki } \\
\text { je odgovor izbralo }\end{array}$ \\
\hline $\begin{array}{l}\text { a) Učenci se nepravilno in nejasno izražajo } \\
\text { glede na veljavne jezikovne norme. }\end{array}$ & 13 \\
\hline $\begin{array}{l}\text { b) Učenci imajo težave pri oblikovanju različnih } \\
\text { besedilnih zvrsti (pismo, članek ...). }\end{array}$ & 6 \\
\hline $\begin{array}{l}\text { c) Učenci ne zmorejo samostojno } \\
\text { argumentirati, razložiti ali opisati svojih } \\
\text { čustev ipd. }\end{array}$ & 5 \\
\hline $\begin{array}{l}\text { č) Učenci imajo težave pri samostojnem pisanju } \\
\text { obnove besedila. }\end{array}$ & / \\
\hline $\begin{array}{l}\text { d) Učenci ne zmorejo ustrezno preoblikovati } \\
\text { besedila. }\end{array}$ & / \\
\hline e) drugo & \\
\hline
\end{tabular}


Po mnenju učiteljev se na področju pisnega sporočanja težave kažejo predvsem kot nepravilno in neustrezno izražanje glede na veljavne jezikovne norme, učenci ne zmorejo samostojno argumentirati, razložiti ali opisati svojih čustev, mnenj ipd., imajo težave pri samostojnem pisanju obnove besedila ter pri oblikovanju različnih besedilnih zvrsti.

Pomemben princip v metodiki poučevanja ruščine kot tujega jezika je med drugim upoštevanje materinščine, njeno primerjanje $\mathrm{z}$ jezikom, ki se ga učimo, iskanje podobnosti in razlik. Učitelje ruščine smo vprašali, ali znanje slovenščine kot maternega in hkrati slovanskega jezika pozitivno ali negativno vpliva na učenje ruščine.

Tabela 15: Ali po vašem mnenju znanje slovenščine kot maternega in hkrati slovanskega jezika pozitivno ali negativno vpliva na učenje ruščine?

\begin{tabular}{|l|c|}
\hline Odgovori & $\begin{array}{c}\text { Število učiteljev, ki } \\
\text { je odgovor izbralo }\end{array}$ \\
\hline $\begin{array}{c}\text { a) pozitivno (pozitivni transfer, podobnosti } \\
\text { med jezikoma olajšajo učenje ruščine) }\end{array}$ & 12 \\
\hline $\begin{array}{c}\text { b) negativno (interferenca, znanje } \\
\text { slovenščine povzroča zmedo pri } \\
\text { usvajanju ruščine) }\end{array}$ & 1 \\
\hline c) pozitivno in negativno & 16 \\
\hline č) ne pozitivno ne negativno & $/$ \\
\hline
\end{tabular}

Večina vprašanih je mnenja, da znanje slovenščine pri učenju ruščine kot tujega jezika vpliva tako negativno kot tudi pozitivno. Dvanajst učiteljev meni, da znanje slovenščine vpliva zgolj pozitivno ter tako omogoča pozitivni transfer med jezikoma in uspešnejše učenje. Samo eden od vprašanih je mnenja, da znanje slovenščine vpliva zgolj negativno.

\subsection{Težave in napake slovenskih učencev pri razvijanju jezikovnih zmožnosti}

Jezikovne zmožnosti vključujejo leksikalno, fonološko, skladenjsko znanje in spretnosti ter druge razsežnosti jezika kot sistema, neodvisno od sociolingvistične vrednosti njegovih različic in pragmatičnih funkcij njegovega udejanjanja (Skupni evropski jezikovni okvir 2011). Šibko (2014) jezikovno (lingvistično) kompetenco razume kot skupek znanj o jezikovnem sistemu, o pravilih funkcioniranja jezikovnih enot v govoru ter kot zmožnost za uporabo jezikovnega sistema pri izražanju misli.

Najpogostejše napake, ki se po mnenju učiteljev pojavljajo pri učenju ruščine na posameznih jezikovnih področjih, so prikazane v Tabeli 16. 
Tabela 16: Na katerib jezikovnih področjih prihaja do največ napak pri učenju ruščine?

\begin{tabular}{|l|c|}
\hline Odgovori & $\begin{array}{c}\text { Število učiteljev, ki } \\
\text { je odgovor izbralo }\end{array}$ \\
\hline $\begin{array}{c}\text { a) na področju skladnje (pri tvorjenju vsebinsko } \\
\text { in slovnično pravilnih povedi, enostavna } \\
\text { poved, zapletena poved, besedni red ...) }\end{array}$ & 3 \\
\hline $\begin{array}{c}\text { b) na področju besedoslovja (prepoznavanje } \\
\text { besednih pomenov, iskanje sopomenk in } \\
\text { protipomenk, blizuzvočnice ...) }\end{array}$ & 3 \\
\hline $\begin{array}{c}\text { c) na področju oblikoslovja (sklanjanje } \\
\text { samostalnika, spreganje glagola ...) }\end{array}$ & 3 \\
\hline $\begin{array}{c}\text { č) na področju glasoslovja (glasovna znamenja, } \\
\text { naglas, fonetika) }\end{array}$ & 3 \\
\hline $\begin{array}{c}\text { d) pri pisavi in upoštevanju pravopisnih pravil } \\
\text { (pisanje in branje cirilice, ločila) }\end{array}$ & 6 \\
\hline
\end{tabular}

Večina učiteljev ruščine je mnenja, da se pri slovenskih učencih najpogostejši jezikovni odkloni kažejo na področju oblikoslovja (sklanjanje samostalnika, spreganje glagola ipd.). Šest vprašanih je izpostavilo težave pri pisavi in upoštevanju pravopisnih pravil, zgolj po trije vprašani so kot problematična opredelili področja besedoslovja, skladnje ali glasoslovja.

Podrobnejša razčlenitev napak in težav na posameznih jezikovnih področjih je privedla do naslednjih rezultatov, ki so predstavljeni v Tabelah 17, 18 in 19.

Tabela 17: Kje zasledite najpogostejše jezikovne odklone od norme na področju glasoslovja?

\begin{tabular}{|l|c|}
\hline Odgovori & $\begin{array}{c}\text { Število učiteljev, ki } \\
\text { je odgovor izbralo }\end{array}$ \\
\hline $\begin{array}{c}\text { a) pri zapisu in razumevanju uporabe jotiranih in } \\
\text { nejotiranih samoglasnikov (a-я, э-е, о-ё,y-ю, b-и) }\end{array}$ & 15 \\
\hline $\begin{array}{c}\text { b) pri zapisu in razumevanju uporabe trdih in mehkih } \\
\text { soglasnikov (npr. parni soglasniki, vedno mehki } \\
\text { soglasniki - ч,щ, vedno trdi soglasniki - ш, }, \text { ц) }\end{array}$ & 2 \\
\hline c) pri zapisu in razumevanju uporabe črke j/й & 1 \\
\hline č) pri zapisu in razumevanju uporabe črke l/л & 11 \\
\hline $\begin{array}{l}\text { d) pri zapisu in izgovoru naglašenih in nenaglašenih } \\
\text { samoglasnikov (npr. redukcija nenaglašenih } \\
\text { samoglasnikov) }\end{array}$ & \\
\hline
\end{tabular}

Na področju glasoslovja se težave najpogosteje pojavljajo pri zapisu in razumevanju uporabe jotiranih in nejotiranih samoglasnikov ter pri zapisu in izgovoru naglašenih in nenaglašenih samoglasnikov. 
Tabela 17: Kje zasledite najpogostejše jezikovne odklone od norme pri pregibnib besednih vrstah?

\begin{tabular}{|l|c|}
\hline Odgovori & $\begin{array}{c}\text { Število učiteljev, ki je } \\
\text { odgovor izbralo }\end{array}$ \\
\hline a) pri samostalniški besedi & 8 \\
\hline b) pri pridevniški besedi & 9 \\
\hline c) pri glagolu & 11 \\
\hline
\end{tabular}

Jezikovni odkloni, povezani s pregibnimi besednimi vrstami, so porazdeljeni enakomerno. Enajst vprašanih največ težav ugotavlja pri uporabi glagola, sledita še pridevniška in samostalniška beseda.

Tabela 18: Kje zasledite najpogostejše jezikovne odklone od norme pri nepregibnih besednih vrstah?

\begin{tabular}{|l|c|}
\hline Odgovori & $\begin{array}{l}\text { Število učiteljev, ki } \\
\text { je odgovor izbralo }\end{array}$ \\
\hline a) pri prislovu & 5 \\
\hline b) pri predlogu & 15 \\
\hline c) pri vezniku & 2 \\
\hline c) pri členku & 1 \\
\hline c) pri medmetu & 1 \\
\hline
\end{tabular}

Pri nepregibnih besednih vrstah se največ težav pojavlja pri uporabi predloga, sledijo mu prislov, veznik ter členek in medmet.

S pomočjo tristopenjske ocenjevalne lestvice smo želeli ugotoviti, katere slovnične kategorije, povezane s samostalnikom, pridevnikom in glagolom, so najzahtevnejše za učence ruščine. Učitelji so na omenjeni ocenjevalni lestvici obkrožili številko, ki ustreza težavnosti posamezne slovnične kategorije - številka 1 pomeni 'nezahtevno', številka 2 - 'srednje zahtevno', številka 3 - 'zelo zahtevno'.

Z vprašanji o težavah pri pravilni uporabi samostalnika smo izvedeli, katera slovnična kategorija je za učence ruščine najzahtevnejša (spol, število, sklon) ter pri uporabi katerega sklona se pojavlja največ težav.

Tabela 19: Katere slovnične kategorije, povezane s samostalnikom, so po vašem mnenju za učence ruščine najzabtevnejšs?

\begin{tabular}{|l|c|c|c|}
\hline Odgovori & \multicolumn{3}{|c|}{ Ocenjevalna lestvica } \\
\hline & 1-nezahtevno & 2-srednje zahtevno & 3-zelo zahtevno \\
\hline Spol samostalnika & 20 & 9 & $/$ \\
\hline Število samostalnika & 16 & 13 & $/$ \\
\hline Sklon samostalnika & 2 & 8 & 19 \\
\hline
\end{tabular}


Spol samostalnika so vprašani najpogosteje opredelili kot nezahtevno kategorijo. Število samostalnika slovenskim učencem ne povzroča večjih težav - 16 učiteljev ga je opredelilo kot nezahtevno. Najpogostejše jezikovne odklone je opaziti pri uporabi sklonov, ki je po mnenju večine učiteljev ruščine zelo zahtevna kategorija.

Tabela 20: Pri uporabi katerega sklona se pojavlja največ težav?

\begin{tabular}{|l|c|}
\hline Odgovori & $\begin{array}{c}\text { Število učiteljev, ki } \\
\text { je odgovor izbralo }\end{array}$ \\
\hline a) pri imenovalniku & $/$ \\
\hline b) pri rodilniku & 15 \\
\hline c) pri dajalniku & 1 \\
\hline c) pri tožilniku & 2 \\
\hline c) pri mestniku & 5 \\
\hline c) pri orodniku & 4 \\
\hline
\end{tabular}

Največ težav učitelji ugotavljajo pri pravilni uporabi rodilnika, sledijo mu mestnik, orodnik, tožilnik in dajalnik.

Pri pridevniški besedi so morali učitelji s pomočjo ocenjevalne lestvice določiti stopnjo zahtevnosti za naslednje kategorije: končnice pridevnikov v imenovalniku ednine in množine, trda in mehka osnova pridevnika, polna in kratka oblika pridevnika, sklanjatve pridevnikov ter stopnjevanje pridevnikov.

Tabela 21: Katere slovnične kategorije, povezane spridevnikom, so po vašem mnenju za učence ruščine najzabtevnejše?

\begin{tabular}{|l|c|c|c|}
\hline Odgovori & \multicolumn{3}{|c|}{ Ocenjevalna lestvica } \\
\hline & 1-nezahtevno & 2-srednje zahtevno & 3-zelo zahtevno \\
\hline $\begin{array}{l}\text { Končnice pridevnikov v im. } \\
\text { ed. in im. mn. }\end{array}$ & 9 & 15 & 4 \\
\hline $\begin{array}{l}\text { Trda in mehka osnova } \\
\text { pridevnika }\end{array}$ & 2 & 15 & 12 \\
\hline $\begin{array}{l}\text { Polna in kratka oblika } \\
\text { pridevnika }\end{array}$ & 3 & 13 & 12 \\
\hline Sklanjatve pridevnikov & $/$ & 13 & 15 \\
\hline Stopnjevanje pridevnika & 3 & 17 & 8 \\
\hline
\end{tabular}

Končnice pridevnikov v imenovalniku ednine in množine ter trdo in mehko osnovo pridevnikov je večina učiteljev največkrat opredelila kot srednje zahtevni kategoriji. Precej podobno so učitelji opredelili tudi polno in kratko obliko pridevnika. Sklanjanje pridevnikov je bilo največkrat opredeljeno kot zelo zahtevno ali kot srednje zahtevno področje. Stopnjevanje pridevnikov velja za srednje zahtevno kategorijo. 
Pomembno vlogo pri učenju ruščine kot tujega jezika igra tudi glagol. Na tristopenjski ocenjevalni lestvici so se učitelji odločali o zahtevnosti posameznih slovničnih kategorij, povezanih z glagolom.

Tabela 22: Katere slovnične kategorije, povezane z glagolom, so po vašem mnenju za učence ruščine najzabtevnejše?

\begin{tabular}{|l|c|c|c|}
\hline Odgovori & \multicolumn{3}{|c|}{ Ocenjevalna lestvica } \\
\hline & 1-nezahtevno & 2-srednje zahtevno & 3-zelo zahtevno \\
\hline Spreganje glagolov & 5 & 21 & 3 \\
\hline Glagolski časi & 6 & 18 & 5 \\
\hline $\begin{array}{l}\text { Nedoločne glagolske oblike } \\
\text { (nedoločnik, deležniki, deležja) }\end{array}$ & 3 & 8 & 16 \\
\hline $\begin{array}{l}\text { Glagolski naklon (velelnik, } \\
\text { pogojnik, povednik) }\end{array}$ & 3 & 18 & 7 \\
\hline $\begin{array}{l}\text { Glagolski vid (dovršnik, } \\
\text { nedovršnik) }\end{array}$ & 2 & 14 & 12 \\
\hline Glagoli premikanja & 1 & 2 & 25 \\
\hline Glagolski način (tvorni, trpni) & $/$ & 14 & 12 \\
\hline Povratni glagoli & 5 & 15 & 7 \\
\hline $\begin{array}{l}\text { Vezljivost glagolov/glagolska } \\
\text { rekcija }\end{array}$ & $/$ & 10 & 15 \\
\hline
\end{tabular}

Največkrat so se učitelji odločali med stopnjama 'srednje zahtevno' in 'zelo zahtevno'. V zelo zahtevno področje sodijo glagoli premikanja, nedoločne glagolske oblike ter glagolska rekcija oz. vezljivost glagolov. Kot srednje zahtevno kategorijo so učitelji največkrat opredelili spreganje glagolov, glagolske čase, glagolski naklon ter povratne glagole. Kategoriji glagolskega vida in načina je 14 vprašanih opredelilo za srednje zahtevni kategoriji, 12 vprašanih pa je kategoriji opredelilo kot zelo zahtevni.

\subsection{Popravljanje napak pri učenju ruščine kot tujega jezika}

Napake in težave je potrebno razumeti kot spremljajoči pojav pri učenju, njihova korektura pa mora pozitivno vplivati na učenca, saj lahko sicer izgubi motivacijo. Učitelj mora učencu napake predstaviti skupaj s pravilnimi oblikami, pri tem pa mora upoštevati učenčevo ustvarjalnost in mu pomagati (Muster-Čenčur 1997). Ko govorimo o korekturi, moramo razlikovati med dvema učnima fazama (Muster-Čenčur 1997: 110, povzeto po Demme 1996), in sicer med:

a) jezikovno fazo, ki je namenjena delu z jezikom (npr. slovnične vaje), zato mora učitelj zahtevati slovnično pravilnost, napake sproti popravljati, učencem pa posredovati povratno informacijo o pravilnosti oz. napakah; 
b) komunikacijsko fazo, kjer je v ospredju vsebina sporočila in realizacija komunikacijskih namer, zato učitelj ne prekinja miselnega toka učenca, ampak si napake sproti beleži. Popraviti je potrebno le izraze, ki onemogočajo razumevanje sporočila ali so povsem neprimerne.

Zadnji sklop vprašanj so predstavljala tri vprašanja o tem, kako učitelji popravljajo napake pri ustni produkciji in pisnem sporočanju ter o tem, ali vsebinsko pravilen odgovor pri nalogah, ki zahtevajo razumevanje, negativno točkujejo zaradi slovničnih napak (Tabele 23, 24 in 25).

Tabela 23: Na kakšen način popravljate napake pri ustni produkciji?

\begin{tabular}{|l|c|}
\hline Odgovori & $\begin{array}{c}\text { Število učiteljev, ki je } \\
\text { odgovor izbralo }\end{array}$ \\
\hline a) Vse napake dosledno popravljam. & 6 \\
\hline $\begin{array}{l}\text { b) Napake so sestavni del učenja in jih } \\
\text { ne popravljam. }\end{array}$ & $/$ \\
\hline $\begin{array}{l}\text { c) Popravim le napake, ki se pojavijo } \\
\text { redno. }\end{array}$ & 15 \\
\hline $\begin{array}{l}\text { c) Popravim napake, ki se mi zdijo } \\
\text { najpomembnejše. }\end{array}$ & $/$ \\
\hline $\begin{array}{c}\text { c) Učenci samostojno popravljajo } \\
\text { napake v parih ali skupinah. }\end{array}$ & $/$ \\
\hline c) drugo & \\
\hline
\end{tabular}

Več kot polovica učiteljev pri ustni produkciji popravi le napake, ki se jim zdijo najpomembnejše. Osem učiteljev popravlja le tiste napake, ki se pojavljajo redno, šest pa vse napake dosledno popravlja. Nihče od vprašanih ne uporablja možnosti, da bi učenci samostojno popravili napake v skupinah ali parih.

Tabela 24: Na kakšen način popravljate napake pri pisnib izdelkih?

\begin{tabular}{|l|c|}
\hline Odgovori & Število učiteljev, ki je odgovor izbralo \\
\hline a) Sam/a označim in popravim napake. & 11 \\
\hline b) Napake le označim, učenci jih nato sami popravijo. & 5 \\
\hline $\begin{array}{c}\text { c) Učenci med seboj zamenjajo teste in samostojno } \\
\text { popravljajo napake drugih. }\end{array}$ & $/$ \\
\hline $\begin{array}{c}\text { c) Navedem le skupno število napak v posamezni } \\
\text { nalogi, učenec pa jih nato sam prepozna in popravi. }\end{array}$ & 7 \\
\hline $\begin{array}{l}\text { c) Samostojno pregledam teste, glavne napake pa v } \\
\text { razredu skupinsko popravimo. }\end{array}$ & \begin{tabular}{c} 
6 \\
\hline c) drugo
\end{tabular} \\
\hline
\end{tabular}


Pri pisni produkciji učitelji najpogosteje sami označijo in popravijo napake, večkrat tudi napake le označijo in jih učenci samostojno ali skupinsko popravijo oz. kombinirajo različne načine popravljanja.

Tabela 25: Ali vsebinsko pravilen odgovor pri nalogah, ki zahtevajo razumevanje, negativno točkujete zaradi slovničnih napak?

\begin{tabular}{|l|c|}
\hline Odgovori & $\begin{array}{c}\text { Število učiteljev, ki } \\
\text { je odgovor izbralo }\end{array}$ \\
\hline a) da & 5 \\
\hline b) ne & 24 \\
\hline
\end{tabular}

Večina vprašanih (83 \%) vsebinsko pravilen odgovor pri nalogah, ki zahtevajo razumevanje, ne točkuje negativno zaradi slovničnih napak.

\section{ZAKLJUČEK}

Metodika poučevanja in učenja ruščine kot tujega jezika je znanstvena disciplina $\mathrm{z}$ lastnim zgodovinskim razvojem in teoretičnimi izhodišči, ki služijo kot osnova slehernemu učitelju pri načrtovanju in izvajanju pouka ruščine. Učenje ruščine v tujem socialno-jezikovnem okolju ima svoje specifične lastnosti, ki se jih je potrebno zavedati in upoštevati.

S pomočjo vprašalnika za učitelje ruščine in njegove analize smo dobili prvi vpogled v stanje na področju učenja in poučevanja ruščine kot tujega jezika v slovenskem prostoru. Z zastavljenimi vprašanji ni mogoče ugotoviti vrste drugih problemov, s katerimi se srečujejo učitelji in učenci ruščine v slovenskem prostoru (npr. kolokacije, sintaktične konstrukcije ipd.), je pa omenjena analiza prvi korak na daljši raziskovalni poti. Za natančnejše ugotovitve bi bilo potrebno izvesti dodatne, podrobnejše in obsežnejše raziskave. Raziskovalci omenjenega področja $v$ slovenskem prostoru vedno znova naletimo na težave zaradi majhnega števila udeležencev v vzorcu, zato se moramo zaenkrat zadovoljiti z raziskavami, ki ne omogočajo posploševanja, vseeno pa prinašajo zanimive izsledke in iztočnice za nadaljnje raziskovanje in razmislek.

Ruščina se kot tuji jezik uči in poučuje na osnovnih šolah, gimnazijah, fakultetah ter na različnih jezikovnih šolah in tečajih. V skladu z rezultati vprašalnika lahko trdimo, da se na tako majhnem prostoru, kot je slovenski, za učenje ruščine uporablja pestra množica učbenikov (11). Razlog za omenjeno raznovrstnost lahko najdemo v bogati izbiri učbenikov, ki jo ponuja predvsem ruski trg, poleg tega pa v Sloveniji (še) nimamo uradno potrjenega učbenika, ki bi ga lahko uporabljali v osnovnih in srednjih šolah. Najpogosteje uporabljeni učbeniki (npr. učbenik Poehali) ne upoštevajo specifičnih težav slovenskega učenca pri učenju ruščine ali jezikovnih primerjav med slovenščino in ruščino. Večina učbenikov vključuje avdio-vizualno gradivo, ki ga učitelji tudi uporabljajo, slaba lastnost pa je, da ne vključujejo didaktičnega priročnika za učitelja. Vsi učitelji (tudi) zato učencem posredujejo 
dodatni material (npr. delovne liste), predvsem z vajami za utrjevanje slovnice in slovničnih pravil. Kot dodatni material učitelji uporabljajo predvsem avtentične avdio in video posnetke, neprirejena ruska besedila ali slikovno gradivo.

Kot glavne vzroke za težave pri učenju ruščine kot tujega jezika so učitelji opredelili različne sposobnosti učencev, premalo tedenskih ur, neredno opravljanje domačih nalog in neustrezne učbenike. Pri razvijanju različnih zmožnosti učitelji največ težav opažajo pri pisnem sporočanju (mogoče tudi zato, ker je omenjena zmožnost največkrat predmet preverjanja) - učenci se nepravilno in neustrezno izražajo glede na veljavne jezikovne norme. Na področju slušnega razumevanja največ težav predstavlja razumevanje neprirejenih ruskih besedil. Tudi pri bralnem razumevanju so v ospredju težave $\mathrm{z}$ razumevanjem sporočila prebranega neprirejenega besedila ter pri prepoznavanju podrobnosti. Pri ustnem sporazumevanju se učenci najpogosteje izražajo nepravilno glede na jezikovne norme, vendar je njihovo sporočilo še vedno razumljivo. Največ napak na področju govornega sporočanja učitelji ugotavljajo pri samostojnem argumentiranju, razlaganju ali opisovanju učenčevih mnenj, čustev ipd.

Najpogostejše jezikovne odklone učitelji ruščine opažajo pri oblikoslovju (samostalniku, pridevniški besedi, glagolu in predlogu). Kot zelo zahtevno kategorijo, povezano s samostalnikom, so učitelji opredelili sklone, še posebej rodilnik. Pri pridevniku so kot zelo zahtevno označili sklanjanje, pri glagolu pa nedoločne glagolske oblike, vezljivost in glagole premikanja.

Učitelji se zavedajo, da lahko slovenski jezik uporabimo kot pomembno oporo pri učenju ruščine, z opozarjanjem tako na negativni kot na pozitivni transfer. Pri načrtovanju pouka ruskega jezika se učitelji največkrat sklicujejo na učni načrt (48\%), veliko manj pa na maturitetni katalog (20\%), Program učenja ruščine kot tujega jezika (rus. Образовательная программа по русскому языку как иностранному) (15\%) ali na Skupni evropski okvir smernic za učenje in poučevanje jezikov (17\%).

Učenje in poučevanje ruščine v slovenskem prostoru in izobraževalnem sistemu počasi pridobiva svoje mesto med ostalimi tujimi jeziki (npr. angleščino, nemščino, francoščino). S strokovnim delom, neprestanim izpopolnjevanjem ter medsebojnim sodelovanjem lahko k temu pomembno prispevamo tudi učitelji ruščine.

\section{BIBLIOGRAFIJA IN VIRI}

BYKOVA, Ol'ga P., (2014) Obučenie russkomu jazyku kak inostrannomu v inojazyčnoj srede. Moskva: Russkij jazyk. Kursy.

KRJUČKOVA, Ljudmila S./ Natalija V MOŠČINSKAJA (2009) Praktičeskaja metodika obučenija russkomu jazyku kak inostrannomu. Moskva: Flinta. Nauka.

LEBEDENSKIJ, Sergej I./ Ljudmila F. GERBIK (2011) Metodika prepodavanija russkogo jazyka kak inostrannogo. Učebnoe posobie. Minsk: UDK. BBK.

MOSKOVIN, Leonid V./ Anatolij N. ŠČUKIN (2013) Istorija metodiki obučenija russkomu jazyku kak inostrannomu. Moskva: Russkij jazyk. Kursy. 
MUSTER-ČENČUR, Ana M. (1997) Napake slovenskih učencev pri učenju nemškega jezika (analiza, sistematizacija in predlog aplikacije). Doktorska disertacija. Univerza v Ljubljani: Filozofska fakulteta. Oddelek za germanske jezike in književnosti.

KOMAROVA, Tatjana (2014) Uroki russkogo 1: sem'ja? -> [s'imjá] = 7«ja«: vvodnyjfonetiko-razgovornyj kurs. Ljubljana : Znanstvena založba Filozofske fakultete.

Ministerstvo obrazovanija Rossijskoj federacii. Obrazovatel'naja programma po russkomu jazyku kak inostrannomu. Predvuzovskoe obučenie. (2011) Moskva:. 15. September 2015. http://web-local.rudn.ru/web-local/uem/inyas/2/HTML1/Doc/PrgrRus3.pdf.

PASSOV, Efim I. (2010) Urok inostrannogo jazyka. Moskva: Glossa-Press. Rostov na Donu: Feniks.

PIRIH SVETINA, Nataša (2003) Napaka v ogledalu procesa učenja tujega jezika. Jezik in slovstvo. Ljubljana: Slavistično društvo Slovenije. 48 (2), 17-26.

SPANRING-POREDOŠ, Marina, 2014: Ja i ty ... ... mi in vi: učebnik dlja načinajuščih. Ljubljana: Znanstvena založba Filozofske fakultete.

Skupni evropski jezikovni okvir: učenje, poučevanje, ocenjevanje. (2011) Ljubljana: Ministrstvo RS za šolstvo in šport Urad za šolski razvoj. 1. oktober 2015. http://www.europass.si/files/userfiles/europass/SEJO\%20komplet\%20za\%20splet.pdf.

ŠČUKIN, Anatolij N. (2003) Metodika prepodavanija russkogo jazyka kak inostrannogo. Moskva: Vysšaja škola.

ŠIBKO, Natal'ja L. (2014) Obščie voprosy metodiki prepodavanija russkogo jazyka kak inostrannogo. Sankt-Peterburg: Zlatoust.

URBAS, Janja (2006) Situacii, mnenija, upražnenija. Situacije, mnenja, vaje. Ljubljana: Bartus.

URBAS, Janja/Ines VOZELJ (2008) Učni načrt. Ruščina: gimnazija: splošna, klasična, strokovna gimnazija: obvezni predmet in matura (420 ur), izbirni predmet (140 ur). Ljubljana: Ministrstvo za šolstvo in šport. Zavod RS za šolstvo. 1. oktober 2015. http:// portal.mss.edus.si/msswww/programi2008/programi/media/pdf/ucni_nacrti/UN_RUSCINA_gimn.pdf.

URBAS, Janja/Ines VOZELJ (2009) Učni načrt za izbirni predmet. Ruščina:osnovna šola. Ljubljana: Ministrstvo za šolstvo in šport. Zavod RS za šolstvo. 1. oktober 2015. http:// www.mizs.gov.si/fileadmin/mizs.gov.si/pageuploads/podrocje/os/devetletka/predmeti_izbirni/Ruscina_izbirni.pdf

VARAKSINA, Viktorija A. (2014) Rečevye ošibki inostrannyh studentov i pričiny ih vozniknovenija. Jazyk $i$ tekst langpsy.ru. № 1. 30. september 2015. http://langpsy.ru/journal/2014/1/Nurmuhhmetov.phtml.

VJATJUTNEV, Mark N. (1981) Teorija učebnika russkogo jazyka kak inostrannogo (metodičeskie osnovy). Moskva: Russkij jazyk.

VUČO, Julijana (2012) O učenju jezikov: pogled v zgodovino glotodidaktike: od pradavnine do druge svetovne vojne. Ljubljana: Znanstvena založba Filozofske fakultete.

VYGOTSKIJ, Lev S. (2010) Mišljenje in govor. Ljubljana: Pedagoška fakulteta. 


\section{POVZETEK}

\section{Poučevanje ruščine kot tujega jezika v slovenskem prostoru}

V prvem delu pričujočega prispevka je predstavljenih nekaj bistvenih teoretičnih izhodišč metodike poučevanje ruščine kot tujega jezika ter njen kratek zgodovinski oris. V drugem delu prispevka se avtorica osredotoča na poučevanje in učenje ruskega jezika v slovenskem prostoru. Predstavljeni so rezultati vprašalnika za učitelje ruščine, s pomočjo katerega je avtorica izvedela, kje se ruščina poučuje, kakšna gradiva se pri tem uporabljajo in na katerih področjih ugotavljajo učitelji največje težave pri učenju in usvajanju ruskega jezika.

Ključne besede: metodika poučevanja ruščine kot tujega jezika, tuje jezikovno okolje, napaka

\section{ABSTRACT}

\section{Teaching Russian as a Foreign Language in Slovenia}

The first part of the paper presents a few essential theoretical premises of the methodology of teaching Russian as a foreign language and its brief historical outline. In the second part of the paper the author focuses on the teaching and learning of Russian in Slovenia. The author presents the results of a questionnaire for teachers of Russian, which let her know where Russian language is being taught, which materials the teachers are using, and in which areas they have discovered the biggest problems with learning and mastering the Russian language.

Key words: methodology of teaching Russian as a foreign language, foreign language environment, mistake 